\title{
SOCIAL DISTANCING POLICY AND RESPONSES BY INDONESIAN MUSLIM INTELLECTUALS
}

\author{
Napsiah \\ Universitas Islam Negeri Sunan Kalijaga, Yogyakarta, Indonesia \\ napsiah@uin-suka.ac.id
}

Received: November 29, 2021

Accepted: December 20, 2021

\section{Abstract}

The Covid-19 pandemic has affected Muslim religious practices. Social distancing policy, which requires not to gather for any activities, are contradictory to the Muslim's religious ritual which promotes congregational worship. It accidentally becomes concerns of Muslim intellectuals. Therefore, they publish their thoughts in either national or international journals. This article focuses on the results of the intellectual thoughts published in national journals. It employs descriptive qualitative method through journal searches. There are sixteen related journals deemed to meet the requirements. The results of the study show that the social distancing policy is responded in pros and cons. Those who go with cons do not intend to refuse the government policies but to purely adhere to religious tenet because religion has long been believed while Covid-19 is perceived as a threat. In this sense, they are afraid of religion more than the Covid-19. Meanwhile, those who are pro are subject to not only government regulations but also religion. Therefore, the Covid-19 pandemic has brought about an adaptive attitude of Muslims to remain obedient to the government regulations by carrying out independent religious practices or through virtual spaces.

Pendemi Covid-19 telah berdampak pada praktik keagamaan umat Islam. Kebijakan Social Distancing yang menghendaki tidak berkumpul, bertentangan dengan ritual umat Islam yang mewajibkan ibadah berjemaah. Inilah menjadi 
daya tarik kaum intelektual. Oleh karena itu, mereka mempublikasikan pemikirannya di berbagai jurnal baik internasional maupun nasional. Artikel ini berfokus pada hasil pemikiran intelektual yang dipublikasikan di jurnal nasional. Penelitian kualitatif deskriptif diperoleh melalui penelusuran jurnal, terdapat 16 jurnal bertema Islam yang dianggap memenuhi persyaratan. Hasil pemikiran kaum intelektual menunjukkan bahwa kebijakan sosial distancing direspons pro dan kontra. Golongan yang kontra dalam hal ini bukan menolak kebijakan pemerintah tetapi lebih pada menunjukkan ketaatan pada agama yang jauh sebelumnya diyakini, sedangkan Covid-19 adalah ancaman. Dalam posisi ini mereka lebih takut pada agama daripada Covid-19. Sedangkan yang pro tidak hanya tunduk pada peraturan pemerintah, tetapi juga tunduk pada agama. Dengan demikian, pandemi Covid-19 membawa sikap adaptif umat Islam untuk tetap patuh pada peraturan pemerintah dengan menjalankan praktik keagamaan secara mandiri atau melalui ruang virtual.

Keywords: Intellectual's thoughts; social distancing policy; the Covid-19 pandemic; Islamic religious practices

\section{Introduction}

Social distancing is a policy implemented by countries exposed to Covid-19 Indonesia. The policy was implemented in March 2020 which ended up with working at home policy or what is known as Work from Home (Herdiana, 2020). The policy aims to reduce direct contact with humans as the Covid-19 virus transmits through direct contact (Duan et al., 2020; Lingam \& Suresh Sapkal, 2020; Iizuka, 2020; Mishra \& Majumdar, 2020), so that the social distancing policy which aims to reduce the transmission process becomes relevant (Djalante et al., 2020). In relation to the policy, closing public places such as mosques is the main effort of the government because mosques are considered a place for people to gather (Mishra \& Majumdar, 2020; Yurianto \& Yurianto, 2020). Besides, the policy also requires a ban on holding meetings, such as social gatherings, celebrations, or wedding receptions that violate protocols (Nurhayati \& Halal, 2020). The government only allows the opening of traditional markets with a very limited time.

This phenomenon opens up the eyes of Indonesian's intellectuals because it accidentally happens (Ulhaq et al., 2020; Suyadi et al., 2020; Muhtada, 2020; Agustino, 2020; Efendi, 2021; Hidayati \& Fahlevi , 2020; Yusuf \& Dua, 2019; Kusumaningtyas, 2021; Arrobi \& Nadzifah, 2020). Therefore, ideas related to social distancing and physical distancing are disseminated and 
widely spread through journals so that they are accessible to the public. The articles published are used as references for not only scientific development but also policy making related to the social distancing policy.

Researches on social distancing policy have been widely published in national and international journals, which can be characterized into several categories: 1 ) articles that specifically study about the socio-religious practices of Muslims (Husni et al., 2020; Rizal, \& Azis, 2020; Suyadi et al., 2020; Ulhaq et al., 2020). They place more emphasis on studies of responses and impacts as well as public perceptions related to the social distancing policy. 2) The relevance of social distancing policy to suppress the acceleration of Covid-19 transmission in the community (Quadri, 2020; Yezli \& Khan, 2020; Tsao et al., 2021; Shaw et al., 2020; Oktari et al., 2020; Chirisa, 2020). They conclude that social distancing is a significant policy to suppress the high rate of spikes in transmission of Covid-19. 3) The impact of the social distancing policy on people's lives. They find that social distancing policy has brought a great impact on economy, psychology and gender (Quadri, 2020; Zhao et al., 2020; Babore et al., 2020; Rana et al., 2021; Zamberlan et al., 2021; Casale \& Posel, 2021; Londoño et al., 2021; Raj et al., 2020; Leung et al., 2020).

A study on Indonesian intellectuals' perception as a whole have not been conducted. Accordingly, the current research complements the gap. It aims to find out the ideas that have been written by Indonesian intellectuals related to the social distancing policy since the implementation of the policy on March 3, 2020. Correspondingly, this research formulates the ideas of the intellectuals related to social distancing policy, the public responses on the social distancing policy, and the impact of the policy on the community.

The arguments built in this research are: firstly, intellectuals write about various ideas according to their respective perspectives. Secondly, the intellectuals' findings in Indonesia are disseminated through articles for references because they show the cases in different areas so that the public's response to the social distancing policy is also diverse. Thirdly, this study is important to enrich the repertoire of studies, especially from a sociological perspective.

\section{Covid-19 and Social Distancing Policy}

The Covid-19 pandemic is basically not a new thing, similar to the disaster happening in 1918 which has made various changes in society (Wan et al., 2020; Jiang et al., 2021). The outbreak is a deadly epidemic (Zhao 
et al., 2020) as was the case in India, where the country has mobilized the entire political system to fight against the Covid-19 pandemic and achieved some initial successes, yet the situation is still showing a commotion in its handling (Zhao et al., 2020). This outbreak has had an impact on people's mental disorders (Duan et al., 2020; Babore et al., 2020; Zhao et al., 2020; Duan et al., 2020; Halaris, 2003). While in the religious field, there is also a change before Muslims congregated in mosques to pray, but in the era of the pandemic all activities carried out in mosques are prohibited, even the house which considered the holiest is also closed. Furthermore, umrah and hajj activities are also stopped because the kingdom of Saudi Arabia has closed the country for pilgrimage (Yezli \& Khan, 2020). This impact has caused enormous trauma at the community level. Distrust of the disease always arises so that there is a frontal attitude or resistance to these conditions, such as keeping mosques open to carry out religious activities. In an effort to suppress the surge in Covid-19 transmission in Indonesia, the government has decided on a large-scale social restriction (PSBB) policy (Junaedi et al., 2021; Yunus \& Rezki, 2020). In this policy, people are expected to limit their activities and maintain a distance or known as social distancing.

Social distancing is an act of limiting population interaction based on the spread of disease to reduce or slow down the spread of disease. It includes three elements, namely: the spread of a disease is the basis for social distancing; the limitation of human interaction which is practically shown by keeping the distance between residents or avoiding crowds; it is aimed at reducing or slowing down the spread of the disease (Kusumaningtyas, 2021).

With the spread of Covid-19 transmission, the social distancing policy has developed into physical distancing. World Health Organization (WHO) is an institution that states that both have the same meaning. They both maintain a distance, but not only socially but also physically. These two terms are an effort to reduce the acceleration of the transmission of Covid-19 both socially and physically. Meanwhile, Indonesia does not use the lockdown policy because it considers the various impacts of lockdown, especially at the economic level. Thus, the social distancing policy is perceived as the ideal way that the government takes to be applied all around the country, even if there are areas where the number of Covid-19 sufferers is not yet high. The policy remains in effect, and there is often a tightening of the policy, with assistance from the local government through the security forces to control community activities. 


\section{The Impact of Social Distancing Policy on Muslims}

The social distancing policy implemented in Indonesia provides a great impact on Muslim community. Muslims, based on Islamic teachings, require crowds or congregations in carrying out social and religious activities (Muhtada, 2020). However, after the policy is enforced, all Muslims carry out their religious activities at home individually. This is a new phenomenon for families in Indonesia. The house is not only a place to live but it is a place to conduct religious activities.

This behavior was suddenly met so that some Muslims are not ready yet to worship at home. Moreover, those who are highly fanatic, often refuse by keeping mosques open and holding gatherings there (Kusumaningtyas, 2021; Aurachman, 2020; Muhaimin, 2020). Belief in Allah is much more appreciated than the coming of Covid-19. Even, Covid-19 is God's creation, so what should be feared is not the Covid-19, but rather the one who creates it, the God Almighty. This belief leads to resistance in many ways. They pray together in the mosques, even carry out learning activities as usual.

The Covid-19 policy also affects the prohibition to perform Umrah and Hajj as it is closed by the Saudi Arabian government. Pilgrims who were already in Saudi Arabia were repatriated as soon as possible by the Saudi Arabian government (Yezli \& Khan, 2020). In addition, Hajj and Umrah activities cannot be carried out in recent years. It causes people's disappointment to the government. In this regard, several issues arise that the government is not alert in anticipating Covid-19 or the government is considered inconsistent in holding the society's money for hajj and umrah. The disappointment is expressed by Muslims throughout the archipelago so that some no longer trust the government.

\section{Intellectual and Social Distancing Policy}

The phenomenon of Covid-19 is a new disaster in Indonesia. The pandemic has devastated people's lives in terms of economic, political, and socio-cultural setbacks. Moreover, religion is in the spotlight which is the most impactful in this regard because when people find no way out for the problems they face, they will return to religion. Religion is a power internalized by the adherents. The policies made by the government successfully grab the attention of academics due to the form of Indonesian intellectual concern. Several policies made in Indonesia during the Covid-19 pandemic have been well documented by them. They are highly concerned with the phenomena 
of this country. The policy has had a number of impacts on changes in social relations and religious practices (Ives \& Kidwell, 2019; Singh, 2017; Muhaimin, 2020; Hidayati \& Fahlevi, 2020).

\section{Methods}

Researches on social distancing policies and Muslim responses have been conducted by Indonesian intellectuals. Various perspectives are used to produce ideas that are worthy reading for wider community. The results of these thoughts are published in journals accessible to all intellectuals. Their thoughts become references for similar studies and basis for policy makers. The results of ideas published in the national journals indexed by Sinta 2, Sinta 3, and Sinta 4, as well as those not indexed accessible through the an Open Journal System (OJS) are the focus of this research.

It is a descriptive qualitative research, with data collection through observation with an ethnographic approach. The search for data starts from the publication of March 2020 until April 2021. There are 16 journal published articles used. In addition, the social distancing policy issued by the Indonesian government and the Indonesian Ulema Council Institution provided online are important for this article. Data analysis is carried out by collecting and mapping journal articles containing social distancing policies and categorizing them based on the month and year of publication.

Table 1. Relevant Papers Based on Journal Publication

\begin{tabular}{|c|c|c|c|c|c|}
\hline No & Autor & $\begin{array}{l}\text { Month/ } \\
\text { year } \\
\text { Publication }\end{array}$ & Journal & $\begin{array}{l}\text { Article } \\
\text { Type }\end{array}$ & Main Purpose \\
\hline 1 & $\begin{array}{l}\text { Nur Rohim } \\
\text { Yunus, Annissa } \\
\text { Rezki }\end{array}$ & $\begin{array}{l}\text { March, } \\
2020\end{array}$ & $\begin{array}{l}\text { SALAM: } \\
\text { Jurnal Sosial } \\
\text { \& Budaya } \\
\text { Syariah } \\
\text { UIN Syarif } \\
\text { Hidayatullah } \\
\text { Jakarta }\end{array}$ & Article & $\begin{array}{l}\text { Describe } \\
\text { government } \\
\text { process to } \\
\text { take lockdown } \\
\text { policy to } \\
\text { anticipate } \\
\text { the spread of } \\
\text { Covid-19 }\end{array}$ \\
\hline
\end{tabular}

el Harakah Jurnal Budaya Islam Vol. 23 No. 2, 2021 


\begin{tabular}{|c|c|c|c|c|c|}
\hline 2 & $\begin{array}{l}\text { Mohammad } \\
\text { Zaki Arrobi, } \\
\text { Amsa Nadzifah }\end{array}$ & $\begin{array}{l}\text { June, } \\
2020\end{array}$ & $\begin{array}{l}\text { Journal } \\
\text { of Ma'arif } \\
\text { Institute for } \\
\text { Humanity }\end{array}$ & Article & $\begin{array}{l}\text { Describe } \\
\text { new religious } \\
\text { authority, the } \\
\text { celebrity cleric } \\
\text { in the media } \\
\text { mass and role } \\
\text { MUI, NU, and } \\
\text { Muhammadiyah } \\
\text { scholars have } \\
\text { the same view } \\
\text { on health } \\
\text { protocol of } \\
\text { covid-19. }\end{array}$ \\
\hline
\end{tabular}

\begin{tabular}{|c|c|c|c|c|c|}
\hline 3 & $\begin{array}{l}\text { Abd Hannan } \\
\text { Siti Azizah } \\
\text { Husna Atiya }\end{array}$ & July, 2020 & $\begin{array}{l}\text { Dinamika: } \\
\text { Academic } \\
\text { Journal of } \\
\text { Islamic Studies }\end{array}$ & Article & $\begin{array}{l}\text { Describe } \\
\text { the response } \\
\text { Pesantren } \\
\text { toward } \\
\text { Covid-19 }\end{array}$ \\
\hline 4 & $\begin{array}{l}\text { Subkhani } \\
\text { Kusuma Dewi } \\
\text { M. Johan } \\
\text { Nasrul Huda }\end{array}$ & July, 2020 & $\begin{array}{l}\text { Dinamika: } \\
\text { Academic } \\
\text { Journal of } \\
\text { Islamic Studies }\end{array}$ & Article & $\begin{array}{l}\text { Describing the } \\
\text { way to pray and } \\
\text { remembrance } \\
\text { of Muslims } \\
\text { in the whole } \\
\text { world to ward } \\
\text { off the danger } \\
\text { of Covid-19 }\end{array}$ \\
\hline
\end{tabular}

\begin{tabular}{|c|c|c|c|c|c|}
\hline 5 & $\begin{array}{l}\text { M. Amin } \\
\text { Abdullah }\end{array}$ & $\begin{array}{l}\text { June, } \\
2020\end{array}$ & $\begin{array}{l}\text { Journal } \\
\text { of Ma'arif } \\
\text { Institute for } \\
\text { Humanity }\end{array}$ & Article & $\begin{array}{l}\text { Dialogue } \\
\text { between } \\
\text { religion } \\
\text { and science } \\
\text { in viewing } \\
\text { Covid-19 }\end{array}$ \\
\hline
\end{tabular}

\begin{tabular}{|c|c|c|c|c|c|}
\hline 6 & $\begin{array}{l}\text { Anung Ahadi } \\
\text { Pradana, } \\
\text { Casman, } \\
\text { Nur'aini }\end{array}$ & $\begin{array}{l}\text { June, } \\
2020\end{array}$ & $\begin{array}{l}\text { Journal of } \\
\text { Kebijakan } \\
\text { Kesehatan } \\
\text { Indonesia: Jkki }\end{array}$ & Article & $\begin{array}{l}\text { Identify the } \\
\text { effect of social } \\
\text { distancing on } \\
\text { vulnerable } \\
\text { groups. }\end{array}$ \\
\hline
\end{tabular}




\begin{tabular}{|c|c|c|c|c|c|}
\hline 7 & $\begin{array}{l}\text { Dadang } \\
\text { Darmwan, } \\
\text { Miharja, Roro } \\
\text { Sri Rejeki } \\
\text { Waluyojati, } \\
\text { Erni Isnaeniah }\end{array}$ & $\begin{array}{l}\text { August, } \\
2020\end{array}$ & $\begin{array}{l}\text { Religious: } \\
\text { Journal of } \\
\text { Studi Agama- } \\
\text { Agama dan } \\
\text { Lintas Budaya }\end{array}$ & Article & $\begin{array}{l}\text { Describe the } \\
\text { anger of the } \\
\text { Muslims who } \\
\text { were against } \\
\text { the social } \\
\text { policy restraint. }\end{array}$ \\
\hline 8 & Leo Agustino & $\begin{array}{l}\text { August, } \\
2020\end{array}$ & $\begin{array}{l}\text { Journal of } \\
\text { Bardoneo } \\
\text { Adminstrasi }\end{array}$ & Article & $\begin{array}{l}\text { Analyze the } \\
\text { policy social } \\
\text { distancing }\end{array}$ \\
\hline 9 & Al Asy'ari & $\begin{array}{l}\text { November, } \\
2020\end{array}$ & $\begin{array}{l}\text { Journal } \\
\text { of Ilmiah } \\
\text { Sosiologi } \\
\text { Agama Prodi } \\
\text { Sosiologi } \\
\text { Agama UIN } \\
\text { SU Medan }\end{array}$ & Article & $\begin{array}{l}\text { Look for } \\
\text { da'wah model } \\
\text { during social } \\
\text { distancing } \\
\text { policy }\end{array}$ \\
\hline 10 & M. Yusuf & $\begin{array}{l}\text { December, } \\
2020\end{array}$ & $\begin{array}{l}\text { Journal of } \\
\text { Nuansa }\end{array}$ & Article & $\begin{array}{l}\text { Identity the } \\
\text { meaning } \\
\text { of Prophet } \\
\text { Muhammad } \\
\text { is migration } \\
\text { related } \\
\text { to facing } \\
\text { pandemics. }\end{array}$ \\
\hline
\end{tabular}

\begin{tabular}{|c|c|c|c|c|c|}
\hline 11 & $\begin{array}{l}\text { Try Bunga } \\
\text { Firma }\end{array}$ & $\begin{array}{l}\text { December, } \\
2020\end{array}$ & $\begin{array}{l}\text { Al-Adyan: } \\
\text { Journal of } \\
\text { Religious } \\
\text { Studies }\end{array}$ & Article & $\begin{array}{l}\text { Describe } \\
\text { the Muslims } \\
\text { religious } \\
\text { practices in the } \\
\text { new normal era }\end{array}$ \\
\hline 12 & $\begin{array}{l}\text { Napsiah dan } \\
\text { Marfuah }\end{array}$ & $\begin{array}{l}\text { December, } \\
2020\end{array}$ & $\begin{array}{l}\text { Journal of } \\
\text { Fikriah }\end{array}$ & Article & $\begin{array}{l}\text { Describe } \\
\text { the role of } \\
\text { technology } \\
\text { as media for } \\
\text { Muslims in } \\
\text { Halal bi halal } \\
\text { event. }\end{array}$ \\
\hline
\end{tabular}




\begin{tabular}{|c|c|c|c|c|c|}
\hline 13 & $\begin{array}{l}\text { Diajeng Laily } \\
\text { Hidayati, Reza } \\
\text { Fahlevi }\end{array}$ & $\begin{array}{l}\text { December, } \\
2020\end{array}$ & $\begin{array}{l}\text { Journal of } \\
\text { Lentera }\end{array}$ & Article & $\begin{array}{l}\text { Describe the } \\
\text { da'wah on } \\
\text { Covid-19 via } \\
\text { social media }\end{array}$ \\
\hline 14 & $\begin{array}{l}\text { Jujun Junaedi, } \\
\text { Mukhlis } \\
\text { Aliyudin, Dede } \\
\text { Sutisna, Prita } \\
\text { Priantini NC }\end{array}$ & $\begin{array}{l}\text { December, } \\
2021\end{array}$ & $\begin{array}{l}\text { Journal of } \\
\text { Al-Tadabbur: } \\
\text { Jurnal Kajian } \\
\text { Sosial, } \\
\text { Peradaban dan } \\
\text { Agama }\end{array}$ & Article & $\begin{array}{l}\text { Bridgeing } \\
\text { between fatwa } \\
\text { of Nahdatul } \\
\text { Ulama (NU) } \\
\text { about omission } \\
\text { of Friday } \\
\text { prayer and } \\
\text { congregation } \\
\text { replaced the } \\
\text { midday prayer } \\
\text { at home avoid } \\
\text { conflict }\end{array}$ \\
\hline 15 & $\begin{array}{l}\text { AD } \\
\text { Kusumaningtyas }\end{array}$ & $\begin{array}{l}\text { January, } \\
2021\end{array}$ & $\begin{array}{l}\text { Journal of } \\
\text { Muttaqien }\end{array}$ & Article & $\begin{array}{l}\text { Describe } \\
\text { the form of } \\
\text { communication } \\
\text { from Islam } \\
\text { Organization: } \\
\text { NU, } \\
\text { Muhammadiyah } \\
\text { and MUI } \\
\text { related to } \\
\text { Covid-19 }\end{array}$ \\
\hline 16 & Hasse Jubba & $\begin{array}{l}\text { April, } \\
2021\end{array}$ & $\begin{array}{l}\text { Religious: } \\
\text { Journal of } \\
\text { Studi Agama- } \\
\text { Agama dan } \\
\text { Lintas Budaya }\end{array}$ & Article & $\begin{array}{l}\text { Decipher } \\
\text { changes of the } \\
\text { religiosity of } \\
\text { muslim and } \\
\text { christian in } \\
\text { performing } \\
\text { worship } \\
\text { during social } \\
\text { distancing } \\
\text { policy }\end{array}$ \\
\hline
\end{tabular}

Source: Data processed by the researchers

el Harakah Jurnal Budaya Islam Vol. 23 No. 2, 2021 


\section{Results and Discussion}

\section{Social Distancing Policy and Islamic Religious Activities}

The Covid-19 disaster originated from Wuhan was declared a world disaster because all countries have been affected, and it has successfully devastated the lives of people around the world. Indonesia is the 4th most populous country in the world. This virus began to enter Indonesia in the early February, 2020. Soon after the terrible news, the Indonesian government carried out strict supervision to anticipate the spike in transmission of the virus by implementing the Social Distancing Policy (Indriya, 2020). Social distancing aims to anticipate the spike in Covid-19 transmission by limiting direct contact and avoiding crowds (Yunus \& Rezki, 2020). This policy is enforced throughout the archipelago, especially for the open public places, such as traditional markets, malls, and also sports venues.

The Indonesian government has implemented several regulations to anticipate the increase in the number of people exposed to COVID-19. The regulation has been socialized to the public through television, local-national newspapers, radio, and social media so that people are not complacent with the existing conditions. Djalante et al., (2020) summarize several government regulations during the Covid-19 pandemic in Indonesia as the following table.

Table 2. The List of Rules Enforced from February to March 2020

\begin{tabular}{|c|c|c|c|}
\hline Date & Issuing agency & Title of regulation & Reference \\
\hline $\begin{array}{l}\text { February } \\
4,2020\end{array}$ & $\begin{array}{l}\text { Ministry of } \\
\text { Health }\end{array}$ & $\begin{array}{l}\text { Declaration of Novel } \\
\text { infection of Corona virus } \\
\text { as Disease that Can Cause } \\
\text { Plague and its Response } \\
\text { Measures }\end{array}$ & $\begin{array}{l}\text { The decision of } \\
\text { MoH No: HK.01.07/ } \\
\text { MENKES/104/20 } 20\end{array}$ \\
\hline $\begin{array}{l}\text { February } \\
28,2020\end{array}$ & $\begin{array}{l}\text { BNPB } \\
\text { (National } \\
\text { disaster } \\
\text { management } \\
\text { agency) }\end{array}$ & $\begin{array}{l}\text { Declaration of Special } \\
\text { Emergency Situation of } \\
\text { COVID-19 Epidemic } \\
\text { Disaster in Indonesia }\end{array}$ & $\begin{array}{l}\text { The decision of Head } \\
\text { of BNPB 9A/2020 }\end{array}$ \\
\hline $\begin{array}{l}\text { March } \\
13,2020\end{array}$ & $\begin{array}{l}\text { President of } \\
\text { Indonesia }\end{array}$ & $\begin{array}{l}\text { Presidential Decree } \\
\text { (Keppres) 9/2020) }\end{array}$ & $\begin{array}{l}\text { Presidential Decree } \\
\text { (Keppres) 9/2020) }\end{array}$ \\
\hline $\begin{array}{l}\text { March } \\
14,2020\end{array}$ & $\begin{array}{l}\text { Ministry of } \\
\text { Finance }\end{array}$ & $\begin{array}{l}\text { Distribution of Special } \\
\text { Grant Allocation for } \\
\text { Infrastructure in Health } \\
\text { Sector and Grants for } \\
\text { Health Operation for } \\
\text { COVID-19 response }\end{array}$ & $\begin{array}{l}\text { The decision of MoF } \\
6 / \text { KM.7/2020 }\end{array}$ \\
\hline
\end{tabular}

el Harakah Jurnal Budaya Islam Vol. 23 No. 2, 2021 


\begin{tabular}{|c|c|c|c|}
\hline $\begin{array}{l}\text { March } \\
16,2020\end{array}$ & $\begin{array}{l}\text { Assembly } \\
\text { Indonesia } \\
\text { Cleric }\end{array}$ & Mosque Closing Appeal & MUI Fatwa 14/2020 \\
\hline $\begin{array}{l}\text { March } \\
16,2020\end{array}$ & $\begin{array}{l}\text { Ministry of } \\
\text { Health }\end{array}$ & $\begin{array}{l}\text { A network of COVID-19 } \\
\text { Laboratories }\end{array}$ & $\begin{array}{l}\text { The decision of } \\
\text { MoH HK. 01.07/ } \\
\text { MENKES/182/2020 }\end{array}$ \\
\hline $\begin{array}{l}\text { March } \\
16,2020\end{array}$ & $\begin{array}{l}\text { Ministry of } \\
\text { Finance }\end{array}$ & $\begin{array}{l}\text { Distribution and the Use } \\
\text { of Shared Income Grant, } \\
\text { Fiscal Allocation, General } \\
\text { Allocation Grant, Special } \\
\text { Allocation Grant and } \\
\text { Regional Incentives for } \\
2020 \text { Fiscal Response to } \\
\text { COVID-19 }\end{array}$ & $\begin{array}{l}\text { MOF Regulation No: } \\
\text { 19/PMK.07/2020 }\end{array}$ \\
\hline $\begin{array}{l}\text { March } \\
20,2020\end{array}$ & $\begin{array}{l}\text { National } \\
\text { Police } \\
\text { (POLRI) }\end{array}$ & $\begin{array}{l}\text { Prohibition of Mass } \\
\text { Gathering of Group } \\
\text { Activity both in Public } \\
\text { and Local Environments }\end{array}$ & $\begin{array}{l}\text { Kapolri Mandate No. } \\
\mathrm{MAK} / 2 / \mathrm{III} / 2020\end{array}$ \\
\hline $\begin{array}{l}\text { Maret } \\
20,2020\end{array}$ & $\begin{array}{l}\text { President of } \\
\text { Indonesia }\end{array}$ & $\begin{array}{l}\text { Revision of Keppres on } \\
\text { Task Force for Rapid } \\
\text { Response to COVID-19 }\end{array}$ & $\begin{array}{l}\text { President Instruction } \\
\text { (Keppres) 9/2020) }\end{array}$ \\
\hline $\begin{array}{l}\text { Maret } \\
20,2020\end{array}$ & $\begin{array}{l}\text { President of } \\
\text { Indonesia }\end{array}$ & $\begin{array}{l}\text { Refocusing of Activities, } \\
\text { Fiscal Allocation, } \\
\text { and Procurement of } \\
\text { Goods and Services } \\
\text { for the Acceleration of } \\
\text { COVID-19 Response }\end{array}$ & $\begin{array}{l}\text { President Instruction } \\
\text { (Inpres 4/2020) }\end{array}$ \\
\hline $\begin{array}{l}\text { March } \\
20,2020\end{array}$ & $\begin{array}{l}\text { Ministry of } \\
\text { Finance }\end{array}$ & $\begin{array}{l}\text { Tax incentives for } \\
\text { Compulsory Tax Holders } \\
\text { Affected by COVID- } 19\end{array}$ & $\begin{array}{l}\text { Mof Regulation No: } \\
\text { 23/PMK.03/2020 }\end{array}$ \\
\hline $\begin{array}{l}\text { Maret } \\
20,2020\end{array}$ & $\begin{array}{l}\text { Ministry of } \\
\text { Communication } \\
\text { and } \\
\text { Information }\end{array}$ & $\begin{array}{l}\text { Acceleration of } \\
\text { Socialization of } \\
\text { COVID-19 Prevention at } \\
\text { Provincial and District/ } \\
\text { City Levels }\end{array}$ & $\begin{array}{l}\text { Circulated Letter SE } \\
2 / 2020\end{array}$ \\
\hline $\begin{array}{l}\text { March } \\
24,2020\end{array}$ & $\begin{array}{l}\text { Village, } \\
\text { Regional } \\
\text { Disadvantage } \\
\text { and } \\
\text { Transmigration } \\
\text { Minister }\end{array}$ & $\begin{array}{l}\text { Village Response for } \\
\text { COVID-19 and Cash for } \\
\text { Work in Villages }\end{array}$ & $\begin{array}{l}\text { Circulated Letter SE } \\
8 / 2020\end{array}$ \\
\hline
\end{tabular}

el Harakah Jurnal Budaya Islam Vol. 23 No. 2, 2021 


\begin{tabular}{|c|c|c|c|}
\hline $\begin{array}{l}\text { March } \\
31,2020\end{array}$ & $\begin{array}{l}\text { President of } \\
\text { Indonesia }\end{array}$ & $\begin{array}{l}\text { National Budgeting } \\
\text { Policy and the Stability } \\
\text { of Budgeting System for } \\
\text { COVID-19 Pandemic } \\
\text { Disaster and/or } \\
\text { Managing Threats for } \\
\text { National Economy and/ } \\
\text { or the Stability Budgeting } \\
\text { System }\end{array}$ & $\begin{array}{l}\text { Government } \\
\text { Regulation in Lieu of } \\
\text { Law No } 1 / 2020\end{array}$ \\
\hline $\begin{array}{l}\text { March } \\
31,2020\end{array}$ & $\begin{array}{l}\text { President of } \\
\text { Indonesia }\end{array}$ & $\begin{array}{l}\text { National Budgeting } \\
\text { Policy and the Stability } \\
\text { of Budgeting System for } \\
\text { COVID-19 Pandemic } \\
\text { Disaster and/or } \\
\text { Managing Threats for } \\
\text { National Economy and/ } \\
\text { or the Stability Budgeting } \\
\text { System }\end{array}$ & $\begin{array}{l}\text { Government } \\
\text { Regulation in Lieu of } \\
\text { Law No } 1 / 2020\end{array}$ \\
\hline $\begin{array}{l}\text { March } \\
31,2020\end{array}$ & $\begin{array}{l}\text { President of } \\
\text { Indonesia }\end{array}$ & $\begin{array}{l}\text { National Budgeting } \\
\text { Policy and the Stability } \\
\text { of Budgeting System for } \\
\text { COVID-19 Pandemic } \\
\text { Disaster and/or } \\
\text { Managing Threats for } \\
\text { National Economy and/ } \\
\text { or the Stability Budgeting } \\
\text { System }\end{array}$ & $\begin{array}{l}\text { Government } \\
\text { Regulation in Lieu of } \\
\text { Law No } 1 / 2020\end{array}$ \\
\hline $\begin{array}{l}\text { March } \\
31,2020\end{array}$ & $\begin{array}{l}\text { President of } \\
\text { Indonesia }\end{array}$ & $\begin{array}{l}\text { Declaration of } \\
\text { Community Health } \\
\text { Emergency Situation for } \\
\text { COVID-19 }\end{array}$ & $\begin{array}{l}\text { President Decree No } \\
11 / 2020\end{array}$ \\
\hline $\begin{array}{l}\text { March } \\
31,2020\end{array}$ & $\begin{array}{l}\text { President of } \\
\text { Indonesia }\end{array}$ & $\begin{array}{l}\text { Big Scale Social } \\
\text { Restriction for } \\
\text { Accelerating COVID-19 } \\
\text { Eradication }\end{array}$ & $\begin{array}{l}\text { Government } \\
\text { Regulation No } \\
21 / 2020\end{array}$ \\
\hline $\begin{array}{l}\text { July 3, } \\
2021\end{array}$ & $\begin{array}{l}\text { Ministry } \\
\text { of Internal } \\
\text { Affairs }\end{array}$ & $\begin{array}{l}\text { Implementation of } \\
\text { Java-Bali Emergency } \\
\text { Community Activity } \\
\text { (PPKM) Restriction }\end{array}$ & $\begin{array}{l}\text { Introduction of } \\
\text { Ministry of Internal } \\
\text { Affairs No. 15/2021 }\end{array}$ \\
\hline
\end{tabular}

el Harakah Jurnal Budaya Islam Vol. 23 No. 2, 2021 


\begin{tabular}{llll}
\hline August & Ministry & Implementation of & Introduction of \\
3,2021 & of Internal & Java-Bali Emergency & Ministry of Internal \\
& Affairs & Community Activity & Affairs 27 NO. \\
& & Restriction (PPKM). 4 & $27 / 2021$ \\
& & Level for Java-Bali & \\
\end{tabular}

Source: compiled from Djalante et al., 2020

The social distancing policy implemented in Indonesia brings up considerable tension among religious believers, especially Muslim. Islam suggests some religious practices to conduct together in particular places, such as mosques while the policy requires the distanced and independent worship (Darmawan, Miharja, Waluyajati, \& Isnaeniah, 2020 ). Islam requires congregational activities to perform while the rules suggest the other way around, and it is newly socialized. This is a problem for Muslims because it involves religion. Religion is used as a source of knowledge and obedience. When people find no way to solve their problems, they usually return to their God (Jubba, 2021).

The omission of congregational prayers raises pros and cons among society (Quadri, 2020). The pros believe that the transmission of Covid-19 will occur through crowding. Meanwhile, the cons think that the transmission of Covid-19 will not occur in the holy places, such as mosques because the congregations are clean. Covid-19 appears due to human activity, and it is unstoppable. Human knowledge is very limited to solve this problem. Thus, religion becomes an important pillar in human life.

Some religious leaders, such as Qurais Sihab, obey the government's policy and they think it is the right way to avoid the transmission of Covid-19 as the Prophet used to do. There was heavy rain back then, and the roads were muddy, so prayers were carried out in the people's respective homes. At that time, the reason was not on the safety of their soul but on mental health. Correspondingly, the pandemic was closely related to the safety of the soul, so Muslims need to obey the rules to pray at home.

The Muslims who go against the policy by conducting social and religious activities require congregational or gathering activities are a vulnerable group for Covid-19 transmission. Although revealed by Pradana \& Casman (2020) that the vulnerable group refers to the elderly with comorbidities, such as high blood pressure, heart disease, diabetes mellitus, and short breath. However, these vulnerable groups are considered potential for the crowd because their 
consciousness has a stronger belief that there is another power uncontrollable by humans, the power from the omniscient owner of life.

Disaster is a part of national life. His presence seems unavoidable, yet it can only be anticipated and minimized. Even so, disasters will never be destroyed because every natural disaster no longer occurs. Disaster has become the history of human life. As in the case of Indonesia, disasters come one after another, both natural disasters, human disasters, technological disasters and currently disease disasters.

In the midst of the global pandemic due to the spread of Covid-19, religion plays a significant role as a positive-constructive force that participates in mitigating the outbreak and as a reactive force that helps spread the virus (Muhtada, 2020). As a positive force, religion in its manifestations plays a role in preventing the spread of epidemics among religious communities. They have a power to exercise in instructing followers through fatwas that Muslims carry out worship and religious rituals at home or through virtual spaces. Likewise, the priest and cleric has the power to instruct the congregation to eliminate congregational prayers and Friday prayers in mosques and to replace them with congregational prayers at home, even tarawih prayers and activities during the month of Ramadan.

On the other hand, religion can also be a reactive and counterproductive force that contributes to spreading this epidemic through religious rituals involving crowds. This phenomenon has occurred in various countries. In South Korea, the largest center of transmission occurred through the Christian congregation in Shincheonji church, half of the victims infected with the corona virus from the congregation of this church. While in Malaysia, the annual Tablighi Jamaat which was attended by thousands of people from various countries became the center of the spread of this virus in Malaysia, even to Singapore and Indonesia (Jubba, 2021).

\section{Social Change, Religion, and Social Distancing Policy}

Jubba (2021) reveals that the Social Distancing Policy is responded to by Muslims as a form of obedience to the government and an effort to anticipate the transmission of Covid-19. Therefore, Muslims carry out communal worship at home and in confined spaces. In this article, Jubba (2021) is not only limited to Muslims but also Christians. The two religious adherents choose to reduce the practice of communal worship to conform to government policies to reduce the number of Covid-19 transmissions. For Muslims, the 
annual ritual of welcoming Eid al-Fitr by going home, "mudik", meeting with families, has become an annual ritual. But in the era of the pandemic, the ritual is prohibited. Similarly, the Christmas ritual is carried out in the church. The church members greet and smile one another. However, this is not the case in the era of the Covid-19 pandemic. The ritual has changed. In addition to no communal rituals, the congregation also uses masks as a form of submission to health protocols, thus preventing them from greeting or smiling with fellow church members. In such conditions, it is perceived by Christians as the loneliest ritual.

During the Covid-19 pandemic, the behavior of Muslims has also changed (Krimaroca \& Nasution, 2021). Since using a mask, there is no longer a smile or greeting, but rather a response to the delivery to show the intimacy that is carried out by fellow congregants. Therefore, the atmosphere is quiet and social relations are not as close as before.

The commemoration of annual ritual practices, especially halal bihalal (forgiving one another) activities carried out by Muslims every year, has been replaced by meetings through virtual spaces which are very limited by space and time. Napsiah \& Sanityastuti (2020) found that this situation does not replace the closeness of brotherhood but virtual space can replace the moral messages of halal bi halal activity. Even so, this situation becomes relevant because Muslims are adaptive with the situation. According to Abdullah (2020), Muslims actually do not deny that there will be changes after the Covid-19, proven by the obedience of Muslims to close mosques.

Social distancing policies that close mosques and reduce socio-economic and cultural activities of the community must be troubling the community, and religion has the potential to provide spiritual comfort. Therefore Hidayati and Fahlevi (2020) reveals that scholars play an important role in delivering da'wah in the era of the Covid-19 pandemic. Through the video Quraish Shihab, KH. Ahmad Muwafiq, and AA Gym, da'wah carried out through social media is considered the most effective to avoid crowds. From the analysis of the content of the three preachers, three responses were made, conveying information about Covid-19, the importance of maintaining health, cleanliness, obedience to obey government rules and always getting closer to Allah SWT. This approach is called the cognitive approach. This approach is the most fundamental approach taken by Muslims. Thus, it is hoped that Muslims can carry it out without coercion but awareness from within. The affective approach is also used by preachers to convey information about Covid-19. 
Religious appeals require that you always think positively and don't panic about the situation. In addition, the behavioral approach can generate comfort through online recitations and foster solidarity among others, especially for patients affected by Covid-19.

\section{Conclusion}

The social distancing policy, which aims to reduce the number of Covid-19 transmission, attracts scholars' attention in Indonesia. The ideas of these intellectuals have been disseminated through scientific publications to narrate their impacts on society, especially Muslims. They come with diverse ideas, some of which support the government initiative and some oppose it. The counter action is not in the form of rejection against the policies but expression of religious compliance. Meanwhile, the pro attitude is in the form of adherence to religious practices without any coercion because Muslims are adaptive to the conditions during the Covid-19.

This research provides comprehensive knowledge on the thoughts of scientists from various perspectives. The thoughts are disseminated in the Covid-19 era, especially for Muslims, so they no longer perceive that the changes in behavior solely aims to support the government regulations in anticipation to the spike in Covid-19 sufferers. Therefore, Muslims need to be aware that religious practices sometimes need to be adjusted with particular condition, especially in times of disaster.

The current research is still limited to the publications by Muslim writers only. Further studies may examine those from other religions because most religions suggest ritual practices in congregation. Moreover, they can broaden the scope into the international publications.

\section{References}

Abdullah, M. A. (2020). Mendialogkan Nalar Agama dan Sains Modern di Tengah Pandemi Covid-19. Maarif, 15(1), 11-39. https://doi. org/10.47651/mrf.v15i1.75

Agustino, L. (2020). Analisis Kebijakan Penanganan Wabah Covid-19: Pengalaman Indonesia. Jurnal Borneo Administrator, 16(2), 253-270. https://doi.org/10.24258/jba.v16i2.685 
Pradana, A. \& Casman. (2020). Pengaruh kebijakan. Pengaruh Kebijakan Social Distancing pada Wabah Covid-19 Terhadap Kelompok Rentan di Indonesia The, 09(02), 61-67. https://jurnal.ugm.ac.id/jkki/article/view/55575

Arrobi, M. Z., \& Nadzifah, A. (2020). Otoritas Agama di Era Korona: Dari Fragmentasi Ke Konvergensi? Maarif, 15(1), 197-215. https://doi. org/10.47651/mrf.v15i1.85

Aurachman, R. (2020). Konsep Probabilitas untuk Memodelkan Resolusi Antara Ikhtiar, Tawakal, dan Doa dalam Menghadapi Wabah Covid19. Retrieved from https://www.researchgate.net/profile/Rio_Aurachman/ publication/340452951_Konsep_Probabilitas_untuk_Memodelkan_ Resolusi_Antara_Ikhtiar_Tawakal_dan_Doa_dalam_Menghadapi_ Wabah_Covid19/links/5e8ab1f4299bf130798005d0/Konsep-Probabilitasuntuk-Memodelkan-Resolu

Babore, A., Lombardi, L., Viceconti, M. L., Pignataro, S., Marino, V., Crudele, M., Trumello, C. (2020). Psychological effects of the COVID-2019 pandemic: Perceived stress and coping strategies among healthcare professionals. Psychiatry Research, 293(May), 3-8. https://doi.org/10.1016/j. psychres.2020.113366

Casale, D., \& Posel, D. (2021). Gender inequality and the COVID-19 crisis: Evidence from a large national survey during South Africa's lockdown. Research in Social Stratification and Mobility, 71(November 2020). https:// doi.org/10.1016/j.rssm.2020.100569

Chirisa, I. (2020). Disaster Mitigation and Response in Cities: Drawing Lessons from COVID-19 Pandemic. Journal of Social Sciences, 63(1-3). https:// doi.org/10.31901/24566756.2020/63.1-3.2262

Darmawan, D., Miharja, D., Waluyajati, R. S. R., \& Isnaeniah, E. (2020). Sikap Keberagamaan Masyarakat Menghadapi Wabah COVID-19. Religious: Jurnal Studi Agama-Agama Dan Lintas Budaya, 4(2), 115-124. https:// doi.org/10.15575/rjsalb.v4i2.8596

Djalante, R., Lassa, J., Setiamarga, D., Sudjatma, A., Indrawan, M., Haryanto, B., ... Warsilah, H. (2020). Review and analysis of current responses to COVID-19 in Indonesia: Period of January to March 2020. Progress in Disaster Science, 6, 100091. https://doi.org/10.1016/j.pdisas.2020.100091 
Duan, H., Yan, L., Ding, X., Gan, Y., Kohn, N., \& Wu, J. (2020). Impact of the COVID-19 pandemic on mental health in the general Chinese population: Changes, predictors and psychosocial correlates. Psychiatry Research, 293(August). https://doi.org/10.1016/j.psychres.2020.113396

Krimaroca, D, A., \& Nasution, D, R,. (2021). Sikap Pemerintah Ponorogo Dalam Pemberian Efek Jera Terhadap Masyarakat Pasca Uji Coba "New Normal." Jurnal Ilmu Pemerintahan, 14(1), 46-53.

Efendi, M. (2021). Pengelolaan Filantropi Islam Di Tengah Pandemi COVID-19 (Studi Pada Komunitas Kurir Sedekah). Jurnal Manajemen Zakat Dan Wakaf, 2(1), 1-19.

Halaris, A. (2003). Journal of Psychiatric Research: Editorial. Journal of Psychiatric Research, 37(5), 355-356. https://doi.org/10.1016/S00223956(03)00043-8

Herdiana, D. (2020). Social Distancing: Indonesian Policy Reponse To the Corona Virus Disease 2019 (Covid-19). Jurnal Ilmu Administrasi: Media Pengembangan Ilmu Dan Praktek Administrasi, 17(1), 93-110. https://doi. org/10.31113/jia.v17i1.555

Hidayati, D. L., \& Fahlevi, R. (2020a). Dakwah Di Tengah Pandemi (Studi Terhadap Respons Dai Di Media Sosial). Lentera, 4(2). https://doi. org/10.21093/lentera.v4i2.3124

Husni, H., Bisri, H., Tantowie, T. A., \& Rizal, S. S. (2020). Tanggapan Komunitas Beragama terhadap COVID19: Studi kasus komunitas kecil muslim, 24, 10439-10446.

Husni, H., Bisri, H., Tantowie, T. A., Rizal, S. S., \& Azis, A. (2020). Religious Community Responses to COVID-19: Case study on muslim small community. Nternational Journal of Psychosociall Rehabilitation, 24(8), 10439-10446.

Iizuka, A. (2020). Developing capacity for disaster risk reduction: Lessons learned from a case of Sri Lanka. Progress in Disaster Science, 6, 100073. https://doi.org/10.1016/j.pdisas.2020.100073

Indriya, I. (2020). Konsep Tafakkur Dalam Alquran Dalam Menyikapi Coronavirus Covid-19. Salam: Jurnal Sosial Dan Budaya Syar-I, 7 (3). https://doi.org/10.15408/sjsbs.v7i3.15048 
Ives, C. D., \& Kidwell, J. (2019). Religion and social values for sustainability. Sustainability Science, 14(5), 1355-1362. https://doi.org/10.1007/ s11625-019-00657-0

Jacob, C. M., Briana, D. D., Di Renzo, G. C., Modi, N., Bustreo, F., Conti, G., ... Hanson, M. (2020). Building resilient societies after COVID-19: the case for investing in maternal, neonatal, and child health. The Lancet Public Health, 5(11), e624-e627. https://doi.org/10.1016/S24682667(20)30200-0

Jiang, P., Fu, X., Fan, Y. Van, Klemeš, J. J., Chen, P., Ma, S., \& Zhang, W. (2021). Spatial-temporal potential exposure risk analytics and urban sustainability impacts related to COVID-19 mitigation: A perspective from car mobility behaviour. Journal of Cleaner Production, 279. https:// doi.org/10.1016/j.jclepro.2020.123673

Jubba, H. (2021). Beradaptasi dengan Bencana: Strategi Beribadah Umat Islam dan Kristen di Tengah Pandemi Covid-19. Religious: Jurnal Studi Agama-Agama dan Lintas Budaya, 5(1), 1-14. https://doi.org/10.15575/ rjsalb.v5i1.11164

Junaedi, J., Aliyudin, M., Sutisna, D., \& NC, P. P. (2021). Konflik interpretasi fatwa MUI dalam pelaksanaan ibadah selama Pandemi Covid-19. AlTadabbur, 6(2), 175-189.

Kusumaningtyas, A. (2021). Komunikasi Publik Ormas Keagamaan Islam terkait Social Distancing pada Masa Pandemi COVID-19 (Studi atas Sikap Resmi NU, Muhammadiyah, dan MUI). Muttaqien; Indonesian Journal of Multidiciplinary Islamic Studies, 2(01), 21-47. https://doi. org/10.52593/mtq.02.1.02

Leung, T. Y., Sharma, P., Adithipyangkul, P., \& Hosie, P. (2020). Gender equity and public health outcomes: The COVID-19 experience. Journal of Business Research, 116(May), 193-198. https://doi.org/10.1016/j. jbusres.2020.05.031

Lingam, L., \& Suresh Sapkal, R. (2020). COVID-19, Physical Distancing and Social Inequalities: Are We all Really in this Together? The International Journal of Community and Social Development, 2(2), 173-190. https://doi. org/10.1177/2516602620937932

el Harakah Jurnal Budaya Islam Vol. 23 No. 2, 2021 
Mishra, M., \& Majumdar, P. (2020). Social Distancing During COVID-19: Will it Change the Indian Society? Journal of Health Management, 22(2), 224-235. https://doi.org/10.1177/0972063420935547

Muhaimin, W. (2020). Teologi Kemaslahatan Social Phsycal Distancing dalam Penanggulangan Covid-19. Kuriositas: Media Komunikasi Sosial dan Keagamaan, 13(1), 78-102.

Muhtada, D. (2020). Agama dan Mitigasi Wabah COVID-19. CSIS Commentaries DMRU-011, (March).

Napsiah, N., \& Sanityastuti, M. S. (2020). Perubahan Interaksi Sosial Acara Halal bi Halal pada Masa Pandemi Covid-19 di FISHUM UIN Sunan Kalijaga Yogyakarta. Fikrah, 8(2), 295. https://doi.org/10.21043/fikrah. v8i2.7633

Nurhayati, T., \& Halal, R, S. A. (2020). Emansipasi Melawan Pandemi Global ; Bukti Dari Indonesia. Jurnal Adalah: Buletin Hukum dan Keadilan, 4(1), 81-92.

Oktari, R. S., Munadi, K., Idroes, R., \& Sofyan, H. (2020). Knowledge management practices in disaster management: Systematic review. International Journal of Disaster Risk Reduction, 51(August). https://doi. org/10.1016/j.ijdrr.2020.101881

Quadri, S. A. (2020). COVID-19 and religious congregations: Implications for spread of novel pathogens. International Journal of Infectious Diseases, 96, 219-221. https://doi.org/10.1016/j.ijid.2020.05.007

Raj, A., Johns, N. E., Barker, K. M., \& Silverman, J. G. (2020). Time from COVID-19 shutdown, gender-based violence exposure, and mental health outcomes among a state representative sample of California residents. EClinicalMedicine, 26(March). https://doi.org/10.1016/j. eclinm.2020.100520

Rana, I. A., Bhatti, S. S., Aslam, A. B., Jamshed, A., Ahmad, J., \& Shah, A. A. (2021). COVID-19 risk perception and coping mechanisms: Does gender make a difference? International Journal of Disaster Risk Reduction, 55(February). https://doi.org/10.1016/j.ijdrr.2021.102096 
Shaw, R., Kim, Y., \& Hua, J. (2020). Governance, technology and citizen behavior in pandemic: Lessons from COVID-19 in East Asia. Progress in Disaster Science, 6, 100090. https://doi.org/10.1016/j.pdisas.2020.100090

Singh, R. (2017). Use of science and technology as a tool of social change, 2(1), 124-127.

Suyadi, Nuryana, Z., \& Fauzi, N. A. F. (2020). The fiqh of disaster: The mitigation of Covid-19 in the perspective of Islamic educationneuroscience. International Journal of Disaster Risk Reduction, 51. https:// doi.org/10.1016/j.ijdrr.2020.101848

Tsao, S.-F., Chen, H., Tisseverasinghe, T., Yang, Y., Li, L., \& Butt, Z. A. (2021). What social media told us in the time of COVID-19: a scoping review. The Lancet Digital Health, 7500(20), 1-20. https://doi.org/10.1016/ s2589-7500(20)30315-0

Ulhaq, Z. S., Kristanti, R. A., Hidayatullah, A. A., Rachma, L. N., Susanti, N., \& Aulanni'am, A. (2020). Data on attitudes, religious perspectives, and practices towards COVID-19 among Indonesian residents: a quick online cross-sectional survey. Data in Brief, 32. https://doi.org/10.1016/j. dib.2020.106277

Valencia Londoño, P. A., Nateras González, M. E., Bruno Solera, C., \& Paz, P. S. (2021). The exacerbation of violence against women as a form of discrimination in the period of the COVID-19 pandemic. Heliyon, 7(3). https://doi.org/10.1016/j.heliyon.2021.e06491.

Wan, Y., Shang, J., Graham, R., Baric, R. S., \& Li, F. (2020). Receptor Recognition by the Novel Coronavirus from Wuhan: an Analysis Based on Decade-Long Structural Studies of SARS Coronavirus. Journal of Virology, 94(7). https://doi.org/10.1128/jvi.00127-20

Yezli, S., \& Khan, A. (2020). COVID-19 social distancing in the Kingdom of Saudi Arabia: Bold measures in the face of political, economic, social and religious challenges. Travel Medicine and Infectious Disease, 37(April), 7-10. https://doi.org/10.1016/j.tmaid.2020.101692

Yunus, N. R., \& Rezki, A. (2020). Kebijakan Pemberlakuan Lock Down Sebagai Antisipasi Penyebaran Corona Virus Covid-19. Salam: Jurnal Sosial dan Budaya Syar-I, 7(3), 227-238. https://doi.org/10.15408/sjsbs.v7i3.1508

el Harakah Jurnal Budaya Islam Vol. 23 No. 2, 2021 
Yurianto, A., \& Yurianto, M. (2020). Positif Corona Meningkat 146 Orang , MUI Larang Shalat Jumat.

Zamberlan, A., Gioachin, F., \& Gritti, D. (2021). Work less, help out more? The persistence of gender inequality in housework and childcare during UK COVID-19. Research in Social Stratification and Mobility, (July 2020), 100583. https://doi.org/10.1016/j.rssm.2021.100583

Zhao, K., Zhang, G., Feng, R., Wang, W., Xu, D., Liu, Y., \& Chen, L. (2020). Anxiety, depression and insomnia: A cross-sectional study of frontline staff fighting against COVID-19 in Wenzhou, China. Psychiatry Research, 292(April). https://doi.org/10.1016/j.psychres.2020.113304 